\title{
Nursing Schools in northeastern Brazil (1943-1975)
}

\author{
Escolas de enfermeiras no nordeste brasileiro (1943-1975)
}

\author{
Escuelas de enfermería en el nordeste brasileño (1943-1975)
}

\author{
Djailson José Delgado Carlos ${ }^{1}$, Maria Itayra Padilha ${ }^{1}$, Mariana Vieira Villarinho ${ }^{1}$, Miriam Süsskind Borenstein ${ }^{1}$, \\ Ana Rosete Camargo Rodrigues Maia ${ }^{1}$
}

This is a qualitative, narrative and socio-historical study aimed at analyzing the creation of nursing schools in the Northeast of Brazil (1943-1975). The time frame corresponds initially to the creation of the first school and finally to the year in which all the northeastern states founded at least one training institution for nurses. The data collection happened between April and July 2013 using the collection of the Central Library of the Federal University of Santa Catarina and the Study Group about Nursing Knowledge History and Health. About these schools in the Northeast, it is highlighted that their expansion was increased after the University Reform. This situation allowed the local education, abolished the need to travel to other states in search of professional training, enabled a new scenario in educational and health institutions and improvements in health care.

Descriptors: Nursing; History of Nursing; Nursing Education; Higher Education; Education, Nursing, Baccalaureate.

Estudo qualitativo, narrativo, socio histórico, com o objetivo de analisar a criação das Escolas de Enfermeiras no Nordeste brasileiro (1943-1975). 0 recorte temporal corresponde, inicialmente, à criação da primeira escola e o final, ao ano em que todos os estados nordestinos passaram a dispor de instituições formadoras de enfermeiras. A coleta de dados ocorreu entre abril e julho de 2013 e dispôs do acervo da Biblioteca Central, da Universidade Federal de Santa Catarina e do Grupo de Estudos da História do Conhecimento da Enfermagem e Saúde. Sobre estas Escolas no Nordeste, conclui-se que sua expansão foi incrementada após a Reforma Universitária. Essa realidade favoreceu a formação local, aboliu a necessidade de deslocamento a outros estados em busca da profissionalização, possibilitou a um novo cenário nas instituições de ensino e de saúde e, melhorias no cuidado à saúde.

Descritores: Enfermagem; História da Enfermagem; Educação em Enfermagem; Bacharelado em Enfermagem.

Estudio cualitativo, narrativo, socio histórico, con objetivo de analizar la creación de las Escuelas de Enfermeras en el Nordeste brasileño (1943-1975). El inicio del recorte temporal corresponde a la creación de la primera escuela y el final, al año en que todos los estados nordestinos brasileños tuvieron instituciones formadoras de enfermeras. La recolección de los datos ocurrió entre abril y julio de 2013, y se utilizó el acervo de la Biblioteca Central de la Universidad Federal de Santa Catarina y del Grupo de Estudios de Historia del Conocimiento de Enfermería y Salud. Sobre estas escuelas nordestinas, se concluye que su expansión fue incrementada después de la Reforma Universitaria. Esa realidad favoreció la formación local, abolió la necesidad de locomoción a otros estados, posibilitó nuevo escenario en las instituciones de enseñanza y de salud, y mejorías en la atención a la salud.

Descriptores: Enfermería; Historia de la Enfermería; Educación en Enfermería; Bachillerato en Enfermería.

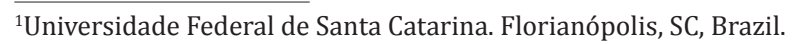

Corresponding author: Maria Itayra Padilha

Programa de Pós-Graduação em Enfermagem da UFSC, Campus Universitário, s/no - Trindade, CEP: 88040-970 - Florianópolis, SC, Brazil. E-mail: padilha@ccs.nfr.br
} 


\section{Introduction}

In Brazil, the creation and operation of the Nursing School of the Departamento Nacional de Saúde Pública (DNSP) [National Department of Public Health] in the city of Rio de Janeiro, capital of the republic at that time, marks the introduction of the Anglo-Saxon system, known worldwide as Modern Nursing. Currently known as Escola de Enfermagem Anna Nery (EEAN) [Anna Nery Nursing School], it emerged as a result of the agreement signed between the Brazilian Government and the Rockefeller Foundation, which sent a group of American nurses in order to train staff to give support to the Health Reform deployed by Carlos Chagas and to the development of the agro-export trade ${ }^{(1-2)}$.

With an innovative character, this school was structured according to the American standards of training nurses, emphasizing the organization, curriculum and candidates' selection process. There was the intention of giving Nursing a new professional configuration, thus justifying the requirement of a higher education course or equivalent to the candidates, considered a high educational level at that time, in an attempt to attract socially privileged women $^{(3)}$.

Concerning the nursing schools in northeastern Brazil, the earliest records date back to the 1940s, during the Estado Novo [New State Political Regime] (1937-45), and coincide with the process of industrialization, urbanization of cities and expansion of the social security network through the establishment of social funds. The first initiatives are related to religious groups and occurred in the cities of Fortaleza ${ }^{(4)}$, Ceará (1943) and Recife ${ }^{(5)}$, Pernambuco (1945), all of them with the aim of providing qualified professional training for health services, and in most cases, under the management of the religious orders themselves.

Given the importance of institutionalization of Modern Nursing in Brazil and its consequences to the professionalization of Brazilian women, this study aims to analyze the creation and institutionalization of Nursing schools in northeastern Brazil (1943-1975).

\section{Method}

This is a qualitative study, with a historical approach, of narrative type which aims at the comprehension of man's actions as a being who is able to act, interact and transform himself, others and reality, set in a particular context, in order to elucidate different aspects of everyday social life ${ }^{(6)}$.

By historical research, one understands it as research that is presented as a strategy able to answer questions about the past, allowing the researcher to investigate the traces and signs left by the past, as well as use the activation and reactivation of memory so that new knowledge is generated. To do so, one must work on the sources in a contextualized and critical perspective, by submitting it to rigorous methodological criteria. This type of study, fundamentally narrative and systematic, contributes to the knowledge of the history of societies and professions. It is relevant to foster an understanding of the context lived through careful analysis of the past, at the present time, of a particular time and to allow the identification of future questions ${ }^{(7)}$.

The elaboration of this article, which occurred between the months of May and August 2013, was possible due to some documentary sources, such as Laws, Decrees and Resolutions, as well as books, academic productions, publications in journals, reports that deal with the History of Nursing, History of Nursing Schools and, in particular, the expansion of Nursing Higher Education in Brazil. To do so, it counted on the collection of the Central University Library from the Federal University of Santa Catarina (UFSC) and the Grupo de Estudos da História do Conhecimento da Enfermagem e Saúde (GEHCES) [Study Group about the History of Nursing Knowledge and Health], as well as research in the Database of the Biblioteca Virtual em Saúde (BVS) [Virtual Health Library].

The marker of historical time has its beginning 
with the creation in 1943 of the Nursing School of Fortaleza/CE, regarded as a pioneer in the Northeast and its termination, in the moment when all the Northeastern states began to train nurses (1975). Thus, it was considered as the starting point the creation of the São Vicente de Paulo Nursing School, in Fortaleza, Ceará and as the final milestone, the establishment of the Undergraduate Nursing Course at the Federal University of Sergipe.

The data analysis and interpretation was conducted through careful and detailed reading about the available material for which was prioritized a chronological presentation of events. The resulting data allowed the creation of two figures: the first with the Nursing Schools in Brazil and the second with the Nursing schools in the Northeast. Thus, its implementation was based on the guidelines of Resolution No. 466/12 of the National Health Council ${ }^{(8)}$.

\section{Results}

The results presented here are related to the institutionalization of the teaching of Modern Nursing in Brazil with reference to the creation and operation of the EEAN. The following are two figures: Nursing schools in Brazil (decades of 1920-40) and Nursing schools in the Northeast, both chronologically developed, include the name of the institution, year and location, and the administrative order that they were subordinate, as shown in Figure 1.

Figure 2 shows relevant data to the creation of the Nursing schools and institutionalization of Nursing Undergraduate Studies in Northeastern Brazil (19431975). The information contained was separated intentionally from the previous figure for being the object of analysis of this study. Its construction was made possible from the sources consulted and they are arranged chronologically for easy viewing and understanding.

\begin{tabular}{|l|l|l|}
\hline Institution & Year and place & Administration \\
\hline $\begin{array}{l}\text { EE do National } \\
\text { Pepartment of }\end{array}$ & 1922 - Rio de Janeiro/RJ & Federal Public \\
\hline EE Carlos Chagas & 1933 - Belo Horizonte/MG & State Public \\
\hline $\begin{array}{l}\text { EE Florence } \\
\text { Nightingale }\end{array}$ & 1933 - Anápolis/GO & Protestant \\
\hline $\begin{array}{l}\text { EE da Casa de } \\
\text { Saúde Evangélica }\end{array}$ & 1937 - Rio Verde/GO & Protestant \\
\hline $\begin{array}{l}\text { EE do Hospital São } \\
\text { Paulo }\end{array}$ & 1938 - São Paulo/SP & Catholic \\
\hline EE Luíza Marillac & 1939 - Rio de Janeiro/RJ & Catholic \\
\hline EE de São Paulo & 1942 - São Paulo/SP & State Public \\
\hline $\begin{array}{l}\text { EE do Hosp. São } \\
\text { Vicente de Paulo }\end{array}$ & 1943 - Goiânia/GO & Catholic \\
\hline EE do Estado do Rio & 1944 - Niterói/RJ & Federal Public \\
\hline $\begin{array}{l}\text { EE Rachel Haddock } \\
\text { Lobo }\end{array}$ & 1944 - Rio de Janeiro/RJ & Federal Public \\
\hline EE do Pará & 1944 - Belém/PA & State Public \\
\hline EE Hugo Werneck & 1945 - Belo Horizonte/MG & Catholic \\
\hline $\begin{array}{l}\text { EE Hermantino } \\
\text { Beraldo }\end{array}$ & 1946 - Juiz de Fora/MG & State Public \\
\hline EE Frei Eugênio & 1948 - Uberaba/MG & Catholic \\
\hline $\begin{array}{l}\text { Escola Madre Maria } \\
\text { Teodora }\end{array}$ & 1949 - Campinas/SP & Catholic \\
\hline
\end{tabular}

Figure 1 - Nursing schools in Brazil (decades 1920$40)^{10}$

\begin{tabular}{|l|l|l|}
\hline Institution & Year and place & Administration \\
\hline $\begin{array}{l}\text { EE São Vicente de } \\
\text { Paulo }\end{array}$ & 1943 - Fortaleza/CE & Catholic \\
\hline $\begin{array}{l}\text { EE Nossa Senhora das } \\
\text { Graças }\end{array}$ & 1945 - Recife/PE & Catholic \\
\hline EE da Bahia & 1946 - Salvador/BA & Federal Public \\
\hline EE do Recife & 1947 - Recife/PE & State Public \\
\hline $\begin{array}{l}\text { EE São Francisco de } \\
\text { Assis }\end{array}$ & 1948 - São Luiz/MA & Catholic \\
\hline $\begin{array}{l}\text { EE da Universidade da } \\
\text { Paraíba }\end{array}$ & 1954 - João Pessoa/PB & State Public \\
\hline $\begin{array}{l}\text { EE Santa Emília de } \\
\text { Rodat }\end{array}$ & 1957 - João Pessoa/PB & Catholic \\
\hline EE de Mossoró & 1968 - Mossoró/RN & Municipal Public \\
\hline $\begin{array}{l}\text { Nursing Undergraduate } \\
\text { Course }\end{array}$ & 1973 - Natal/RN & Federal Public \\
\hline $\begin{array}{l}\text { Nursing Undergraduate } \\
\text { Course }\end{array}$ & 1973 - Maceió/AL & Federal Public \\
\hline $\begin{array}{l}\text { Nursing Undergraduate } \\
\text { Course }\end{array}$ & 1973 - Teresina/PI & Federal Public \\
\hline $\begin{array}{l}\text { Nursing Undergraduate } \\
\text { Course }\end{array}$ & 1975 - Aracaju/SE & Federal Public \\
\hline
\end{tabular}

Figure 2 - Nursing schools in the Northeast (19431975)

Source: The authors, 2013 


\section{Discussion}

The institutionalization of Modern Nursing in Brazil that occurred with the operation of the EEAN resulted in an opportunity for women's social mobility ${ }^{(9)}$. The market was large and there were many requests of registered nurses for many different fields of expertise, so that former students in the early years were absorbed by the local market, not moving to other regions of the country. These nurses probably knew they occupied a prominent position among working women and that should keep their prestige, justified by the monthly salary of Rs $700 \$ 000$ (seven hundred réis), paid to the nurses from the Public Health, the highest salaries paid to women in Rio de Janeiro at the time.

Regarding the Nursing Education in the country, some events from that time are noteworthy: changing the name of the Escola de Enfermeiras do DNSP [Nursing School of the DNSP] to Escola de Enfermeiras Dona Ana Neri [Ms. Ana Neri Nursing school] through Decree No. 17.268/26; foundation in 1926, of the Escola Nacional de Enfermeiras Diplomadas Brasileiras (ANED) [National Association of Brazilian Registered Nurses], current Associação Brazileira de Enfermagem (ABEn) [Brazilian Nursing Association]; regulation of the Nursing practice by Decree No. 20.109/31, which also established the Anna Nery Nursing School as a national standard; creation in 1932 of the journal Annaes de Enfermagem [Nursing Annals], nowadays Revista Brasileira de Enfermagem [Brazilian Nursing Journal] (REBEn); approval of the Nurse's Day by Decree No. 2.956/38; conduction in São Paulo, in 1947, of the I I Congresso Brasileiro de Enfermagem [First Brazilian Nursing Congress] (CBEn); regulation of Nursing Education with the enactment of Law No. 775/49; approval of the Project 1.741.B/52 which established the mandatory presence of nurses among Nursing managers; regulation of the professional Nursing practice by Law No. 2.604/55; and the conduction of the Survey of Nursing Resources and Needs in Brazil by ABEn, 1958-59. The synthesis of these data indicates that the decades of 1920s-30s correspond to the installation of Modern Nursing in Brazil and the 1940s-50s, to its consolidation ${ }^{(10-13)}$.

When examining Figure 1, it is necessary to emphasize that the Nursing schools listed on it correspond to the decades from 1920s-40s and that, currently, many of them do not keep their original names, ie, their names do not match those from their creation. These changes occurred for many different reasons: some schools were incorporated to universities, others honored a person or adopted the names of Department or College.

These schools, grounded in moral and social aspects were intended initially to female education and aimed to give Nursing the prestige of a profession under the aspect of a systematic, practical and scientific training. Therefore they wished to make the female professionalization attractive and train nurses to health services.

Still analyzing Figure 1 , it is noticed the existence of a time gap of one decade between the creation of the EEAN and the EE Carlos Chagas. The chronological order of creation of the schools shows that the expansion of Nursing education occurred slowly, most likely for reasons such as: lack of material resources, Nursing as an unknown female profession, strict selection, absorption of former students of the first classes in health services by the country's capital due to attractive local salaries.

It is also noticeable a distributive arrangement of Nursing Schools with concentration in the Southeast, Midwest and North regions, with eleven, three and one, respectively. This distribution, quite unbalanced, with a concentration of schools in the Southeast is justified due to larger socioeconomic and cultural opportunities, as well as its largest demographic quota(14).

Regarding the administration of these schools, two forms are highlighted: public (federal, state or local), and in bigger number, religious (Catholic or Protestant). Their creation/foundation was justified by the need of qualified health care, however they 
attended different interests: the EEAN, by an initiative of the federal government, was designed to support the Health Reform; the EE Carlos Chagas, administratively attached to the state government and focused on the training of religious Catholic nurses; and the EE do Pará, by action of the state government as part of the economic revaluation of the Northern Region through the agreement signed between the Serviço Especial de Saúde Pública (SESP) [Special Public Health Service] and the Institute of Inter American Affair of the United States (IAIA), after World War II for the implementation and development of health $\operatorname{programs}^{(15)}$.

Nevertheless, professional training was required due to the numerical deficiency of nursing staff and the pursuit of efficiency of hospitals' and health services' functioning. Registered nurses were necessary to work in clinical specialties, planning, administration and supervision of health services, as well as to be in charge of staff training ${ }^{(14)}$.

These were the circumstances in which Nursing schools were created, not only in Brazil, considering the context in which Nursing was organized and consolidated in England as a female profession. The St. Thomas' Hospital's Nursing School, founded in London by Florence Nightingale was born under the ascendancy of capitalism and propelled the professional, scientific and systematic qualification under the division of labor, designed for the training of "ladies nurses" (socially privileged, designated to the training, supervision of care and hospital administration) and "nurses' (for patient care, changing bed linen, giving bed baths, administration of medication, diet) ${ }^{(16-17)}$. In the Brazilian reality, the "nurses" correspond to the high-school-level professionals, called Nursing Technicians and Assistants.

Other features may be listed, such as: the shortage of students arising from the social values that the profession is carried out by females in a society where prevailed the concept of male competence ${ }^{(13)}$, with lower intellectual and moral attributes; and the religious or vocational sense that any woman could perform the duties of a nurse. In this regard, the salaries of religious nurses in Brazilian hospitals ranged from $\mathrm{Cr} \$ 100.00$ (one hundred cruzeiros) to Cr\$ 5,000.00 (five thousand cruzeiros), while the lay nurses' salaries were between $\operatorname{Cr} \$ 4,000.00$ (four thousand cruzeiros) and Cr\$22,000.00 (twenty-two thousand cruzeiros), in $1957^{(17)}$. About these values it is important to highlight that the minimum wage was instituted in 1934, during the Era Vargas [President Vargas Political Regime], not being nationally unified and, in 1957, corresponded to Cr\$ 3,800.00 (three thousand and eight hundred cruzeiros).

These few cases illustrate how Nursing is contradictory in its inside. Regarding the social division of labor, the nurse is the professional with greater intellectual ability and responsible for training, service management and supervision of Nursing care, while Nursing technicians and assistants conduct manual, fractionated and lower socially valued activities. Regarding the professional concept between religious and secular, there are huge differences related to technical training and working philosophy of Nursing, as well as the compliance of its financial and institutional interests.

Therefore, the analysis of Figure 2 allows the observation of some similarities with Figure 1, such as: time gap between the creation of Nursing schools across the country since more than two decades elapsed between the creation of the EEAN and the creation of the EE São Vicente de Paulo, in Fortaleza/ CE, in 1943; repetition of this situation in the Northeast, since it took 32 years for all northeastern states to have, on their territories, at least, one school; and the strong presence of religious groups managing the schools.

It was verified that investment, public or private, for the creation of schools did not occur on a regular and continuous basis because the decades following the 1940s show decrease in the number of openings of new institutions. This scenario is mitigated in the 1970s, through the initiative of the federal government, 
after the enactment of the University Reform (Law No. 5.540/68). At this point it is noticeable a discreet male insertion in the profession, although men had already been present in Nursing working as high-school-level professionals.

About this reform, vested since the 1940s, even without having met the expectations of the university community regarding the Nursing Education in the country, it can be analyzed from two perspectives: quantitative (increased supply of vacancies in schools) and qualitative (creation of Graduate Studies and the encouragement of scientific production). This moment was extremely significant because it made possible to resume the creation of new schools across the country, after a slowdown occurred in the $1960 \mathrm{~s}^{(1-}$ 2).

About the institutionalization, consolidation and expansion of Modern Nursing in Brazil, it is noticed that it attended initially the government initiative aimed at public health policies to ensure agro-export economy and, subsequently, acquired new conformations due to the substitution of imports, industrialization, urbanization of cities and the social security model.

Regarding the presence of religious women managing nursing schools, it is known that during the Era Vargas (1930-1945), the Catholic Church established a strong alliance with the state, starting from the Movimento Neocristão [New Christian Movement], which brought back religious popular practices and the vocational awakening. This approach resulted in the use of the Church to expand the reach of political interests among people and in return, financial support and compulsory religious education in the school curricula ${ }^{(18)}$.

To better understand this reality, it is necessary to analyze the two figures, taking as reference the period that corresponds to the Estado Novo [New State Political Regime] (1937-45), during which it is noticed the creation of fourteen new Nursing schools, among which seven under the administration of religious women, distributed as follows: three in the Northeast, three in the Southeast and one in the Midwest.

In this context, it is essential to emphasize the commitment that the Brazilian Nursing Association (ABEn) has been showing when addressing the interests of Brazilian Nursing, throughout its existence, being highlighted here, the Board of Education, which since its creation in 1926, became the main and most traditional representative of Brazilian Nursing, but not the only one. As such it develops, since then, actions aimed at the organization and growth of the profession through the establishment of partnerships and events such as: Nursing Week, Conferences, Seminars, forums, debates and the publishing, since 1932, of the Nursing Annals journal, currently Brazilian Nursing Journal (REBEn) ${ }^{(12-13)}$.

These determinants can assist in understanding the expansion of Nursing schools in Brazil. Studies $^{(1-2)}$ refer to the decades of 1930 s-50s as marked by growth, followed by a period of decline in the 1960s, and resumed after the university reform. It is important to note the decline at that time, of the government investment in public health, strengthening of the curative model and technological development applied to healthcare, which started to require from Nursing Education, again, a new professional training ${ }^{(19)}$. It is, therefore, the adequacy of the professional training to the needs dictated by the economic model, ie, previously focused on agro-export control of epidemics, now with substitution of imports and welfare.

Another factor that may have probably prevented the expansion of schools is related to the regulation of the profession, which occurred only in the 1960s, with the enactment of Law No. 3.780/60, ie, almost four decades after the institutionalization of Modern Nursing in Rio de Janeiro. Since then, the profession started to be regarded as of higher level within the federal public service, ensuring thus, the status of profession at a university level ${ }^{(14)}$.

This event assured the same prerogatives given to other schools of higher education across the country. Until then, by virtue of Law No. 775/49 (It talks about Nursing education in the country 
and repealed Decree No. 20.109/31) it had been established that the creation of new Nursing schools should be compulsorily attached to University Centers or Medicine Colleges, ie, without autonomy and subordinate to these institutions ${ }^{(15)}$.

From the foregoing, it should be stressed that in those northeastern states, where the Higher Education succeeded the university reform, such as in Rio Grande do Norte ${ }^{(19)}$, Alagoas, Piauí and Sergipe, the institutionalization of Modern Nursing had its beginning, in all of them, in the 1950s, with the creation and operation of the Schools of Nursing Assistants, intended for high-school-level professional qualification, such as an unfolding of the Law No. $775 / 49$, which regulates the Nursing education in the country.

\section{Final Considerations}

This study demonstrated that the institutionalization and development of Nursing schools in the Northeast, which began in the 1940s, expresses a close resemblance to events and social, economic, political and cultural happenings in the country. At that time, a qualified professional training was needed, but it was faced with the slow, why not say, stagnation of the creation of new schools in the decades of $1950 \mathrm{~s}-60 \mathrm{~s}$.

The scenario for the university reform and Graduate Studies was modified with the University Reform (1968), which expanded, in a short period of time, the Nursing Higher Education, so that all the Northeastern states started to have almost simultaneously, in the early 1970 s, Undergraduate Courses. These emerged already inserted in the Universities as Centers linked to the Department of Health Sciences and Center of Biomedical Sciences, unlike the Nursing schools, pioneers, which were later incorporated into the Higher Education Institutions.

At this scenario of struggles for responsible training and for the development of Nursing education, ABEn has been, over the years, very important, presenting itself as a facilitator and encouraging factor in the process of supporting the creation and promotion of quality education in Nursing schools.

Finally, this study allowed the understanding of the events and their determinants to the expansion of Nursing education in the Northeast. Their developments have given a new setting in Nursing Services as nurses, graduates of these new schools were admitted to health facilities, public or private, educational or health, religious or secular, which, therefore, represented improvements in training and assistance. Another benefit of the existence of Higher Nursing Education in all states stems from the fact that training started to be local and thus there was no need to travel to other states in search of professional training, enabling a better performance with the regional population.

\section{Collaborations}

Carlos DJD and Padilla MI contributed to the creation, data collection, qualitative analysis of the study, data interpretation, writing of the article and final approval of the version to be published. Villarinho MV, Borenstein MS and Maia ARCR contributed to the qualitative analysis of the study, data interpretation, writing of the article and final approval of the version to be published.

\section{References}

1. Silveira CA, Paiva SMA. A evolução do Ensino de Enfermagem no Brasil: uma revisão histórica. Ciênc Cuid Saúde. 2011. 10(1):176-83.

2. Leonello VM, Miranda Neto MV, Oliveira MAC. Nursing education in Brazil: a historical perspective . Rev Esc Enferm USP. 2011. 45(n. spe):1774-9.

3. Baptista SS, Barreira IA. Enfermagem de nível superior no Brasil e vida associativa. Rev Bras Enferm. 2006; 59(spe):411-6.

4. Silva MGC, Nóbrega-Therrien SM. Reflexão: a formação de enfermeiros e a expansão do ensino 
de Enfermagem no Ceará. Rev Rene. 2006; 7(3):78-84.

5. Costa AANM, César KRV, Schirmer J, Tavares MMF. Obstetrical nurse development at Universidade de Pernambuco, Brazil: a 35-year history. Acta Paul Enferm. 2008; 21(2):361-6.

6. Padilha MI. As ideias que norteiam este livro. In: Padilha MI, Borenstein MS. Santos I. Enfermagem; história de uma profissão. São Caetano do Sul: Difusão; 2011. p. 23-37.

7. Padilha MI, Borenstein MS, Bastini J, Zytkuewisz GV, Lessmann JC. As fontes historiográficas em pauta: a história oral e a pesquisa documental. In: Borenstein MS, Padilha MI. Enfermagem em Santa Catarina: recortes de uma história (1900-2011). Florianópolis: Secco; 2011. p. 37-55.

8. Ministério da Saúde (BR). Conselho Nacional de Saúde, Comissão Nacional de Ética em Pesquisa. Resolução no 466 de 12 de dezembro de 2012: aprova as diretrizes e normas regulamentadoras de pesquisa envolvendo seres humanos. Brasília (DF): Ministério da Saúde; 2012.

9. Barreira IA, Baptista SS, Sauthier J, Santos TCF, Aperibense PGGS, Peres MAA et al. Primeira república: a implantação da Enfermagem laica e seus desdobramentos (1889-1930). In: Padilha MI, Borenstein MS, Santos I. Enfermagem: história de uma profissão. São Caetano do Sul: Difusão; 2011. p. 219-52.

10. Freitas GF. A responsabilidade ético-legal do enfermeiro. In: Oguisso T, organizador. Trajetória histórica e legal da enfermagem. $2^{\underline{a}}$ ed. Barueri: Manole; 2007. p. 209-36.

11. Carvalho AC. Associação Brasileira de Enfermagem, 1926-1976: documentário. 2 ${ }^{\underline{a}}$ ed. Brasília: ABEn Nacional; 2008.

12. Germano RM. Organização da enfermagem brasileira. Enfermagem em Foco. [Internet] 2010 [citado 2013 ago 10]. Disponível em: http://revista.portalcofen.gov.br/index.php/ enfermagem/article/view/3

13. Bock LF, Vaghetti HH, Belleguarda MLR, Padilha MI, Borenstein MS. A organização da Enfermagem e da saúde no contexto da Idade Contemporânea. In: Padilha MI, Borenstein MS, Santos I. Enfermagem: história de uma profissão. São Caetano do Sul: Difusão; 2011. p. 253-94.

14. Associação Brasileira de Enfermagem. Relatório Final do levantamento de recursos e necessidades de enfermagem no Brasil - 1956/1958. Brasília: ABEn; 1980.

15. Silva BR, Baptista SS. O movimento de expansão dos Cursos Superiores de Enfermagem na Região Norte do Brasil. Rev Enferm UERJ. 2007; 15(4):515-200.

16. Costa R, Padilha MI, Borenstein MS, Carvalho MAL. Florence Nightingale (1820-1910): as bases da enfermagem moderna no mundo. In: Padilha MI, Borenstein MS, Santos I. Enfermagem: história de uma profissão. São Caetano do Sul: Difusão; 2011. p. 183-217.

17. Amante LN, Padilha MI, Peres MAA, Gelbcke FL, Maia AR, Anders JC, etal. $O$ cuidado da enfermagem e da saúde no contexto da idade contemporânea (século XIX). In: Padilha MI, Borenstein MS, Santos I. Enfermagem: história de uma profissão. São Caetano do Sul: Difusão; 2011. p.147-81.

18. Gomes TO, Silva BR, Baptista SS, Almeida Filho AJ. Enfermeiras católicas em busca de melhores posições no campo da educação e da prática em Enfermagem nos anos 40 e 50 no Brasil, século XX. Texto Contexto Enferm. 2005; 14(4):506-12.

19. Carlos DJD, Germano RM. A escola de auxiliares de enfermagem de Natal e o Hospital Universitário Onofre Lopes. Rev Rene. 2009; 10(1):72-80. 